TERMINUS

t. 20 (2018), z. 3 (48), s. 283-311

doi: 10.4467/20843844TE.18.015.10084

www.ejournals.eu/Terminus

http://orcid.org/0000-0002-7475-2462

Adam Jegorow

Uniwersytet Jagielloński, Kraków

adam.jegorow@student.uj.edu.pl

\title{
Ars amandi, ars dictandi - średniowieczna Pseudo-Ars amatoria i jej funkcje dydaktyczne w Akademii Krakowskiej
}

\begin{abstract}
Ars amandi, ars dictandi-Medieval Pseudo-Ars amatoria and Its Didactic Functions at Cracow University
\end{abstract}

This paper presents the reception of the medieval didactic poem known as PseudoArs amatoria in the environment of Cracow University. The poem, attributed to Ovid, was most probably written in the $12^{\text {th }}$ century. Three of the codices that include the text are stored in the Jagiellonian Library (BJ 2035, 2115, 2233). Due to the unquestionable fact that the manuscripts were used in the academia, the purpose of the study is to determine the role that Pseudo-Ars amatoria had in the teaching process at Cracow University.

Previous research was devoted to preparing the text's critical edition and pointing out the relationship with amour courtois and the oeuvre of Ovid. Considering the assumptions of Jaussian reception theory, the paper reconstructs the spectrum of reading experiences based on manuscript testimonials that refer to the two above mentioned hypotexts. The main part of the study therefore consists of three chapters. The first one discusses the courtly love motifs present in the work. Based the concept of Peter Allen (The Art of Love: Amatory Fiction from Ovid to the 'Romance of the Rose'), which emphasizes the primary literary dimension of amour courtois, the author stresses the didactic potential of medieval love textbooks. The second chapter is devoted to the medieval reception of Ovid's Ars amatoria, which 
is imitated in the anonymous work in question, and the intertextual connections noticeable at the level of structure and subject matter, due to which Pseudo-Ars amatoria was recognized as the work of the ancient poet, and so endowed with auctoritas, characteristic of school texts. In the third chapter, the author supplements the observations concerning the literary context with an analysis of messages found in Cracow manuscripts. He discusses the contents of the codices and their origin in the context of curriculum reforms related to the growing interest of ars dictaminis, proving the usefulness of the medieval poem in the art of writing. He supports his conclusions with comments regarding other codices. The Boncompagno da Signa's Rota Veneris treaty (BJ 2458) serves as a starting point for the approximation of the basic themes of ars dictaminis, which are then distinguished as the compositional axis of the central part of the poem. In order to document the didactic potential of Pseudo-Ars amatoria, the author refers to information about the 'lost witnesses' of the transmission, Jan of Słupca's codex described by Aleksander Brückner in Medieval Latin Poetry in Poland and the codex of Stanisław Ciołek's chancellery, presented by Bolesław Ulanowski in Liber formularum ad ius Polonicum necnon canonicum spectantium in codice Regiomontano asservatarum, as well as unpublished marginal notes from BJ 2115.

In summary, there are two primary teaching objectives resulting from reading the work in the Cracow University milieu, which correspond to Peter Allen's conclusions regarding the exact meaning of the textbooks of courtly love and the main directions of the reception of Ovid's teaching poems. Pseudo-Ars amatoria was considered a school text, adequate for transmitting the basics of Latin grammar, similar to its ancient model, and, due to the suitable subject matter and applied rhetorical figures, especially useful in explaining the rules of ars dictaminis.

Keywords: Pseudo-Ars amatoria, pseudoovidiana, Cracow University, ars dictaminis

\section{Wstęp}

Jedną z głównych tez, które Denis de Rougemont przedstawił w pracy Miłość a świat kultury zachodniej, była ta o ewolucji nowożytnych wyobrażeń miłości z rozwijającej się w XII wieku poezji dwornej, służącej za nośnik topiki oraz skonwencjonalizowanych postaw 
społecznych i ulegającej procesom twórczego naśladownictwa ${ }^{1}$. Tematem artykułu jest recepcja $\mathrm{w}$ krakowskim środowisku uniwersyteckim jednego z podręczników miłości dwornej, znanego jako Pseudo-Ars amatoria, przekazanego w trzech kodeksach znajdujących się w zbiorach Biblioteki Jagiellońskiej². Obecność tekstu wśród lektur szkolnych skłania do refleksji nad jego potencjałem dydaktycznym i miejscem, jakie zajmował w kanonie. W tym celu, zgodnie z Jaussowskimi koncepcjami recepcji tekstu literackiego, zrekonstruowany zostanie system, w ramach którego powstały trzy wieki wcześniej traktat dialogował $\mathrm{z}$ odbiorcami ${ }^{3}$. Wskazanie wybranych toposów i intertekstualnych aluzji oraz opis świadectw rękopiśmiennych posłużą za narzędzie rekonstrukcji kontekstu, w którym kształtował się horyzont oczekiwań odbiorców decydujących o miejscu utworu w średniowiecznym systemie nauczania.

1 Zob. D. de Rougemont, Miłość a świat kultury zachodniej, przeł. L. Eustachiewicz, Warszawa 1968.

2 Inc. „Si quem forte iuvat subdi sapienter amori”. Inne tytuły pojawiające się w manuskryptach to De amore i De arte procandi. Tekst wydał po raz pierwszy Wilhelm Wattenbach w 1890 roku, wykorzystując w tym celu trzy kodeksy, zob. W. Wattenbach, Pseudoovidische Gedichte des Mittelalters, „Zeitschrift für deutsches Altertum" 34 (1890), s. 270-277. Zdecydowanie większy zakres miała edycja przygotowana w 1968 roku przez Ericha Thiela, który skolacjonował dwadzieścia trzy przekazy, dodając do nich w kolejnych latach pięć nowych świadectw, zob. E.J. Thiel, Mittellateinische Nachdichtungen von Ovids "Ars amatoria“ und „Remedia amoris", "Mittellateinisches Jahrbuch” 5 (1968), s. 115-180. Na tej edycji oparte będą wszystkie dalsze cytowania, zob. także: idem, Neue Handschriften der mittellateinischen Nachdichtungen von Ovids "Ars amatoria" und „Remedia amoris" und Nachträge, „Mittellateinisches Jahrbuch” 9 (1974), s. 248-268.

3 Zob. H.R. Jauss, Historia literatury jako prowokacja dla nauki o literaturze, w: idem, Historia literatury jako prowokacja, przeł. M. Łukasiewicz, Warszawa 1999, s. $145-146$. 


\section{Przekaz Pseudo-Ars amatoria w krakowskich kodeksach}

Krakowskie kopie Pseudo-Ars amatoria zapisane są na kartach trzech piętnastowiecznych kodeksów o sygnaturach: BJ 2115 (k. 532-542), BJ 2233 (k. 77-86), BJ 2035 (k. 106-111), zawierających również towarzyszący w tradycji rękopiśmiennej tekst Pseudo-Remedia amoris ${ }^{4}$. W kodeksie BJ 2035 kopie te przekazano jako część datowanego na XII lub XIII wiek poematu dydaktycznego Facetus ${ }^{5}$. Jak wynika ze wzmianek pozostawionych w dwóch pozostałych rękopisach, autorstwo przypisano Owidiuszowi: titulus w kodeksie BJ 2233 brzmi: „Incipit Ovidius de amore”, a kolofon w rękopisie BJ 2115: „finis Ovidii sine titulo 1442”. Oba kodeksy zostały opatrzone spisem zawartości. Interesująca jest zwłaszcza lista zamieszczona na wewnętrznej stronie okładki kodeksu BJ 2115, która zawiera tytuły dzieł Owidiusza wraz z incipitami, wśród nich „3. fecit librum amoris q.s.i. Si quem forte iuvat subdi sapienter amori”. Również w spisie treści kodeksu BJ 2233 utwór przypisano antycznemu poecie: „Ovidius de amore vagifacetus”. Uwzględniono tym samym glosę „Vagifacetus” dopisa-

4 Ze środowiskiem Akademii Krakowskiej można wiązać zniszczony w czasie II wojny światowej wraz ze znaczną częścią zbiorów Biblioteki Narodowej kodeks kanonika poznańskiego Jana ze Słupcy, przepisany pod dyktando Marcina ze Słupcy, magistra uniwersytetu z 1441 roku; Pseudo-Ars amatoria i Pseudo-Remedia amoris zajmowały karty 67v.-70v. Zawartość kodeksu opisali A. Brückner, Średniowieczna poezya łacińska w Polsce [cz. 1], „Rozprawy Akademii Umiejętności. Wydział Filologiczny" 16 (1892), s. 304-372, oraz E.J. Thiel, Mittellateinische Nachdichtungen..., s. 119-120.

5 Erich Thiel, nie dostrzegając związków z Facetusem, pominął w toku poszukiwań kodykologicznych kodeks BJ 2035. Związki z traktatem wskazał Peter Dronke, który na tej podstawie ustalił datowanie Pseudo-Ars amatoria i Pseudo-Remedia amoris na XII wiek, zob. P. Dronke, Pseudo-Ovid, Facetus, and the Arts of Love, „Mittellateinisches Jahrbuch” 11 (1976), s. 126-131. Pierwsze wydanie krytyczne Facetusa: A. Morel-Fatio, Mélanges de littérature catalane. III - Le livre de courtoisie, „Romania” 15 (1886), s. 224-235 (Pseudo-Ars amatoria i Pseudo-Remedia amoris odpowiadają wersom 131-384). 
ną na karcie 77. w miejscu, w którym kończy się titulus, świadczącą o pamięci literackich powiązań z Facetusem. Na tej podstawie Pseudo-Ars amatoria należy wpisać w tradycję pseudoowidianów wyrastających na gruncie recepcji Owidiuszowej Sztuki kochania oraz średniowiecznych traktatów dydaktycznych ${ }^{6}$.

Za pomocą tytułu Facetus identyfikowano dwa utwory, o incipitach „Cum nihil utilius” oraz „Moribus et vita”, z których drugi zawiera omawiane pseudoowidiana. Oba wyrastają z tradycji podręczników zawierających zasady dobrego zachowania przy stole ${ }^{7}$. Jako takie znalazły zastosowanie w średniowiecznej szkole - znane pod różnymi tytułami (Moralis, Liber de moribus, Moralista) weszły w skład antologii zwanej Liber Catonianus w okresie, gdy kanon autorów późnoantycznych, w tym chrześcijańskich, zaktualizowano przez dodanie dzieł średniowiecznych ${ }^{8}$. Zaważył na tym wyrażony w tytułach moralizatorski charakter traktatu.

Na treść Moralisa składają się zalecenia adresowane do przedstawicieli różnych grup społecznych. Centralną część poematu zajmują Pseudo-Ars amatoria i Pseudo-Remedia amoris, po których następują uwagi na temat wartości przyjaźni oraz rozważania nad cechami

6 Podstawowymi opracowaniami przeglądowymi dotyczącymi średniowiecznych pseudoowidianów są: R.J. Hexter, Shades of Ovid. Pseudo- (and para-) Ovidiana in the Middle Ages, w: Ovid in the Middle Ages, ed. by J.G. Clark, F.T. Coulson, K.L. McKinley, Cambridge 2011, s. 284-309, oraz P. Lehmann, Pseudo-Antike Literatur des Mittelalters, Darmstadt 1964.

7 Zob. C. Segre, Le forme e tradizioni didattiche, w: Grundriss der romanischen Literaturen des Mittelalters, hrsg. von H.U. Gumbrecht, U. Mölk, Bd. 6: La littérature didactique, allegorique et satirique, hrsg. von H.R. Jauss, Heidelberg 1968, s. 86-98.

8 Podstawowym opracowaniem pozostaje M. Boas, De librorum catonianorum historia atque compositione, „Mnemosyne” 42 (1914), s. 17-46. Zwięzły zarys stanu badań podaje A. Dąbrówka, Treści religijne w podręcznikach i lekturach szkolnych, w: Animarum cultura. Studia nad kultura religijna na ziemiach polskich $w$ średniowieczu, red. H. Manikowska, W. Brojer, Warszawa 2008, s. 459-498. Por. K. Stopka, Zakres i program nauczania septem artes $w$ szkołach katedralnych, $\mathrm{w}$ : Septem artes $w$ kształtowaniu kultury umysłowej $w$ Polsce średniowiecznej. Wybrane zagadnienia, red. T. Michałowska, Wrocław 2007, s. 131-132. 
charakteru, jakimi powinien odznaczać się dobry prawnik, lekarz i żołnierz. Odzwierciedlona tu struktura społeczna oraz propagowane modele zachowań są właściwe dla rozwijającej się od XII wieku kultury świeckiej określanej mianem kultury dworskiej. Umieszczone w centrum rozważania o miłości uznano za niezbędne dla formacji młodego chrześcijanina, samo uczucie zaś za istotny czynnik organizujący stosunki społeczne.

\section{Pseudo-Ars amatoria a konwencje miłości dwornej}

W przypadku Pseudo-Ars amatoria konwencje amour courtois dostrzegalne są na poziomie topiki. Peter Dronke wskazał na wiele podobieństw z dwunastowiecznymi traktatami zawierającymi elementy dydaktyki miłosnej, w tym z De amore Andreasa Capellanusa (2. poł. XII w.), uznawanym często, zwłaszcza w dawniejszej literaturze przedmiotu, za modelowy podręcznik miłości dwornej9. Przedmiotem pierwszej księgi wykładu Capellanusa były sposoby zbliżenia się do kobiet, ukazanych zgodnie ze strukturą średniowiecznego społeczeństwa.

Pierwsze zalecenia anonimowej Sztuki kochania dotyczą właściwego doboru kochanki. Nie należy obdarzać uczuciem mniszki, bo oddała serce Bogu, cudzej małżonki, gdyż jej splamienie jest czynem niegodnym (nephas), oraz prostytutki, której względy nigdy nie są bezinteresowne. Godne kochania są natomiast kobiety młode i wdowy - pierwsze ze względu na wiek i urodę, drugie - na doświadczenie (w. 3-18). Istotna jest przy tym pozycja społeczna wybranki:

9 P. Dronke, Pseudo-Ovid..., s. 130-131. Polemiczne koncepcje na temat związków De amore ze zjawiskiem poezji dwornej przedstawili między innymi Paolo Cherchi, Andreas' "De amore": Its Unity and Polemical Origin, w: idem, Andrea Cappellano, i trovatori e altri temi romanzi (Biblioteca di Cultura, 128), Roma 1979, s. 85-111, oraz Don A. Monson, Andreas Capellanus, Scholasticism, and the Courtly Tradition, Washington 2005. 
„Diligat equalem vel paulo se meliorem, / nam cito sepe ruit, qui super astra volat" (w. 27-28) [Niech pokocha równą bądź niewiele wyższą stanem, / gdyż zwykle szybko spada ten, kto wznosi się ponad gwiazdy $]^{10}$. Obsesja na punkcie relacji stanowych, będąca jedną z przyczyn trosk dwornych kochanków, została omówiona w pierwszej księdze traktatu Capellanusa. W tym celu wykorzystał on formę modelowych dialogów, w których przedstawił sposoby nawiązywania miłosnych kontaktów według wypracowanego w literaturze średniowiecznej motywu quinque gradus amoris: visus, alloquium, tactus, osculum, coitus ${ }^{11}$.

Schemat ten przyjęto za podstawę struktury Pseudo-Ars amatoria. Dialog (alloquium) umieszczono w centrum rozważań, poświęcając mu ponad jedną trzecią tekstu (w. 79-124). Zgodnie z topiką romansów rycerskich szczególne znaczenie przypisano spojrzeniu $(v i s u s)^{12}$. Kobieta, zarówno w pobliżu, jak i poza zasięgiem wzroku kochanka, jest źródłem cierpień: „Quando moves oculos, vario certamine pungor, / gaudia corda movent, sed tamen urit amor" (w. 87-88) [Gdy odwracasz wzrok, toczę zmienną walkę / radość porusza serce, lecz spala je miłość]; „,cum te non uideo, pereo cupioque videre, / inspiciens morior, nam nimis urit amor" (w. 105-106) [Gdy cię nie widzę, ginę i zobaczyć pragnę, / widząc, umieram, bo cały płonę z miłości].

Identyfikacja motywów właściwych literaturze dwornej wraz ze świadomością ścisłego powinowactwa tekstu z Facetusem i trakta-

10 Ten i inne przekłady, jeśli nie podano inaczej, pochodzą od autora.

11 Koncepcję gradus amoris średniowiecze wyprowadzało ze znanego fragmentarycznie komentarza Donata do Terencjuszowego Eunucha. Jej źródeł szukano także w wersach Owidiusza, zob. Mateusz z Vendôme, Ars versificatoria, IV 13, w: E. Faral, Les arts poétiques du XII et du XIII siècle. Recherches et documents sur la technique littéraire du Moyen Âge, Paris 1962, s. 183. Na temat ewolucji toposu zob. E.R. Curtius, Literatura europejska i łacińskie średniowiecze, przeł. A. Borowski, Kraków 2009, s. 540-542, oraz L.J. Friedman, Gradus amoris, „Romance Philology” $19(1965 / 66)$, s. $167-177$.

12 Zob. K. Dybeł, Entre la connaissance et l'amour : le regard dans l'univers romanesque de Chrétien de Troyes, Cracovie 2012, s. 121-186. 
tami dydaktycznymi w duchu De amore pozwalały odbiorcom postrzegać go w kategoriach średniowiecznych podręczników miłości. Związki z poezją okazały się jednak problematyczne w momencie, gdy próbowano określić wartość dydaktyczną traktatu; twierdzenie, że przedmiotem wykładu była nauka miłości, byłoby znaczącym uproszczeniem ${ }^{13}$. Istotny zwrot w badaniach nastąpił wraz z publikacją pracy Petera Allena The Art of Love. Amatory Fiction from Ovid

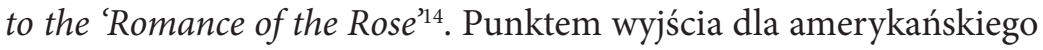
uczonego stała się wyłącznie warstwa literacka i wynikająca z niej fikcyjność utworów obnażana w momencie lektury:

The treatises show their readers not how to feel like lovers, but how to look like them, how to substitute conventional, artificial signs of love for natural and spontaneous ones. Thus the treatises use conventions in the opposite way from the way love poetry does. In love poems, the reader is asked to pretend that conventional motifs are actually natural signs. In the treatises, on the other hand, conventionality is emphasized - not spontaneity, but the intent to signify; not naturalness, but the imitation of nature; not sincerity, but conscious literariness ${ }^{15}$.

[Traktaty pokazują czytelnikom nie jak czuć się kochankami, ale jak ich przypominać, jak zastąpić konwencjonalnymi, sztucznymi oznakami miłości te prawdziwe i spontaniczne. Stąd też traktaty wykorzystują konwencje

13 Miłość dworna jest zjawiskiem literackim, które, co bywa coraz częściej podkreślane, więcej łączy $\mathrm{z}$ dziewiętnastowiecznymi wyobrażeniami na temat kultury XII wieku niż z realiami historycznymi. Termin amour courtois został ukuty w 1883 roku przez Gastona Parisa, zob. G. Paris, Études sur les romans de la Table Ronde : "Lancelot du Lac ”, „Romania” 12, 1883, s. 459-534. Tendencja do demistyfikacji zjawiska przybrała na sile w latach 60 ., czego wyrazem były referaty zebrane $\mathrm{w}$ tomie The Meaning of Courtly Love. Papers of the First Annual Conference of the Center for Medieval and Early Renaissance Studies, ed. by F.X. Newman, Albany 1968. Por. D.A. Monson, Andreas Capellanus..., s. 122-166.

14 P.L. Allen, The Art of Love. Amatory Fiction from Ovid to the Romance of the Rose, Philadelphia 1992. Podstawowe tezy Allen przedstawił we wcześniejszym artykule: idem, "Ars amandi, ars legendi". Love Poetry and Literary Theory in Ovid, Andreas Capellanus and Jean de Meun, „Exemplaria” 1 (1989), s. 181-205.

15 Idem, The Art of Love..., s. 7. 
w przeciwny sposób niż poezja miłosna. W przypadku wierszy miłosnych czytelnik zachęcany jest, by udawać, że konwencjonalne motywy są naturalnymi znakami. W traktatach tymczasem konwencjonalność jest podkreślana - nie spontaniczność, ale zamiar tworzenia znaczeń; nie naturalność, ale imitacja natury; nie szczerość, ale świadoma literackośćc.

Za pomocą średniowiecznych artes amandi uczono zatem nie tyle sposobów zdobycia kobiety, ile wyrażania własnych uczuć oraz interpretowania cudzych deklaracji miłości. Podczas lektury dokonywano dekonstrukcji poezji dwornej, a rezultaty tego działania zależały od znajomości kodu kulturowego, którego częścią była poezja w językach narodowych.

\section{Pseudo-Ars amatoria w świetle recepcji Ars amatoria i Remedia amoris Owidiusza}

Kolejnymi hipotekstami istotnymi dla zrozumienia średniowiecznych kierunków interpretacji Pseudo-Ars amatoria były Owidiuszowe Sztuka kochania i Lekarstwa na miłość. Najstarszy zachowany kodeks, w którym przekazano razem oba poematy, pochodzi z IX wieku' ${ }^{16}$. Od XII wieku liczba rękopisów znacząco rosła, by $\mathrm{w}$ XV stuleciu sięgnąć tysięcy kopii ${ }^{17}$. Istotną rolę $\mathrm{w}$ tym procesie

16 Paris, Bibliothèque nationale de France, Lat. 7311, k. 50v.-103v.; w kodeksie tym zamieszczono również początek pierwszej księgi Amores do wersu 50 drugiej elegii. Por. R. Tarrant, Ovid: "Amores", "Ars amatoria", "Remedia amoris", w: Texts and Transmission. A Survey of the Latin Classics, ed. by L.D. Reynolds, Oxford 1983, s. 261. Istotne uwagi na temat średniowiecznej recepcji Owidiusza oparte na badaniach kodykologicznych, choć ze względu na obszerność materiału, niewykraczające poza XIII wiek, pomieścił w swej pracy Briger Munk Olsen, zob. B.M. Olsen, Ovide au Moyen Âge (du IX e au XII e siècle), w: Le Strade del testo, a cura di G. Cavallo, Bari 1987, s. 67-96.

17 Rosnąca popularność rzymskiego poety w średniowieczu miała charakter wieloaspektowy i nawet najmniejsze próby jej scharakteryzowania wykraczałyby 
odegrała szkoła, w której wciąż posługiwano się kanonem lektur uformowanym w części w epoce przedkarolińskiej; wystarczy wspomnieć, że indeks cytowań dołączony do edycji Grammatici Latini Heinricha Keila zawiera dwadzieścia osiem odniesień do Owidiuszowych elegii dydaktycznych ${ }^{18}$. Z XI wieku z południowych Włoch, zatem $\mathrm{z}$ terenów, gdzie spuścizna antycznych szkół gramatycznych była wciąż żywa, pochodzi kodeks, w którym po raz pierwszy Remedia amoris zostały umieszczone obok tekstów wchodzących w skład Liber Catonianus ${ }^{19}$. Jak wynika ze świadectw rękopiśmiennych, Remedia amoris cieszyły się większą popularnością niż Ars amatoria, były chętniej kopiowane, komentowane i tłumaczone, co więcej, począwszy od XIII stulecia zaczęły zajmować miejsce elegii Maksymianusa wśród Auctores octo jako mniej szkodliwe dla młodych słuchaczy ${ }^{20}$. Istotnym momentem na drodze do ugruntowania ich znaczenia w środowisku szkolnym było włączenie obu poematów w skład innej antologii średniowiecznych podręczników - Libri manuales $^{21}$.

poza zakres artykułu. $\mathrm{Z}$ nowszych opracowań tematu zob. Ovid in the Middle Ages, ed. by J.G. Clark, F.T. Coulson, K.L. McKinley, Cambridge 2011, zebrano tu wcześniejszą bibliografię przedmiotu.

18 Grammatici Latini, ed. H. Keil, t. 7, Lipsiae 1880, s. 609-610. Na temat ewolucji średniowiecznego kanonu lektur zob. G. Glauche, Schullektüre im Mittelalter. Entstehung und Wandlungen des Lektürekanons bis 1200 nach den Quellen dargestellt, Münich 1970.

19 Eton, Eton College Library, MS 150, zob. B.M. Olsen, Ovide au Moyen Âge..., s. 81 .

20 Por. A. Boas, De librorum..., s. 39. Na temat popularności Lekarstw na miłość w średniowieczu zob. E. Pellegrin, Les "Remedia amoris " d'Ovide, texte scolaire médiéval, „Bibliothèque de l'école des Chartes” 115 (1957), s. 172-179, która opiera się przede wszystkim na świadectwach rękopiśmiennych Liber Catonianus.

${ }_{21}$ W ich skład wchodziły również dzieła włączone wcześniej do Liber Catonianus. Strukturę Libri manuales zwięźle omówiła, dołączając katalog 414 kodeksów, E.M. Sanford, The Use of Classical Latin Authors in the Libri Manuales, „Transactions and Proceedings of the American Philological Association" 55 (1924), s. 190-248. Ars amatoria i Remedia amoris zostały wspomniane w dwudziestu jeden antologiach. 
Przyczyny, dla których Remedia amoris wpisano w poczet traktatów o charakterze moralizatorskim, zostały sformułowane w accessus ad auctores - wprowadzeniach do lektury ${ }^{22}$. Zdaniem średniowiecznych egzegetów Remedia amoris powstały w celu odwrócenia szkodliwego wpływu, jaki Sztuka kochania wywierała na prowadzenie się młodych Rzymian. W związku z tym, że dotyczyły ludzkiego zachowania i obyczajności, zaliczono je do etyki. Główna wartość dzieła kryła się w zaleceniach, jak uwolnić się od niedozwolonej miłości (amor illicitus):

Materia huius libri sunt iuvenes et puellae captae de illicito amore, intentio sua est dare praecepta quaedam, quibus illicitum amorem removeat, causa est ut illicito amore detenti expediantur et nondum capti sciant sibi precavere ne capiantur ${ }^{23}$.

[Materią tego dzieła są młodzieńcy i dziewczęta opanowane niedozwoloną miłością. Intencją - podanie pewnych wskazań, jak się od nieprawej miłości uwolnić. Powodem - aby uwikłani w niedozwoloną miłość mogli się z niej wyrwać, a ci, co jeszcze w nią nie wpadli, umieli się od uwikłania w nią ustrzec] $]^{24}$.

Skonfrontowanie w accessus ad auctores obu elegii dydaktycznych sugeruje, że Ars amatoria postrzegano jako moralnie szkodliwą, bo propagującą niedozwoloną miłość. Konrad z Hirschau, autor obszernego szkolnego wprowadzenia Dialogus super auctores, przedstawiając listę zalecanych lektur, wykluczył spośród nich elegie traktujące

22 Zob. E.A. Quain, The Medieval Accessus ad Auctores, „Traditio” 3 (1945), s. 215-264, oraz A. Minnis, Medieval Theory of Authorship. Scholastic Literary Attitudes in the Later Middle Ages, Philadelphia 2010, s. 9-33. Na temat utilitas zob. A. Maciag, Jaki pożytek plynie z czytania? Kwestia utilitas w średniowiecznych accessus ad auctores, „Terminus” 13 (2011), z. 24, s. 31-40. Polskie tłumaczenia accessus za: M. Brożek, Źródła do średniowiecznej teorii wykładu literatury, Warszawa 1989.

${ }^{23}$ Accessus ad auctores: Bernard d'Utrecht, Conrad d'Hirsau. «Dialogus super auctores», éd. critique, entièrement revue et augmentée par R.B.C. Huygens, Leiden 1970, s. 34.

${ }^{24}$ M. Brożek, Źródła do..., s. 85. 
o miłości ${ }^{25}$. Zdaniem autora innego accessus jedyna wartość dydaktyczna Sztuki kochania polegała na odkryciu przed młodzieńcami tajemnic kobiecej natury i metod, za pomocą których można kobietę zdobyć i przy sobie zatrzymać ${ }^{26}$.

Użyteczność dzieła sprowadzono do jego wymiaru moralizatorskiego. Obecnie, gdy poszukiwane są nowe drogi interpretacji tekstu, wykraczające poza warstwę dosłowności jako powierzchowną i przesłaniającą poziomy intertekstualnych aluzji czy ironii, walor dydaktyczny Ars amatoria bywa podawany w wątpliwość: już na poziomie treści oba poematy Owidiusza tworzą parę dzieł wykluczających się ${ }^{27}$. Pomijając jako oczywisty fakt opozycji tematycznej między traktatami, zwrócono uwagę na liczne nawiązania do wcześniejszych elegii ze zbioru Amores, w których erotyczne podboje kończyły się niepowodzeniami, ale mimo to służyły za źródło wiedzy poety nauczyciela ${ }^{28}$. Jednak, jak zauważa Peter Allen, momenty, w których vates pozbawia się autorytetu, wyzwalają podczas aktu lektury sensotwórczy potencjał tekstu: przez odsłonięcie wewnętrznych sprzeczności i przełamanie konwencji epiki dydaktycznej odsłaniane są mechanizmy miłosnej narracji ${ }^{29}$. Śledząc zabiegi dekonstruujące praktyczną stronę przekazywanych instrukcji, odbiorca podczas aktu lektury przenosi swoją uwagę z treści dzieła na warstwę formalną i retoryczno-gramatyczną.

Nawet jeśli nie sposób udowodnić, że proces hermeneutyczny średniowiecznych czytelników przebiegał w podobny sposób, $\mathrm{z}$ analizy zachowanych komentarzy wynika, że Ars amatoria kopiowano w pierwszej kolejności jako źródło do poznania podstaw retoryki

25 Zob. Dialogus super auctores, 1331-1335, w: Accessus ad auctores..., s. 114; M. Brożek, Źródła do..., s. 157.

26 Zob. Accessus ad auctores..., s. 33; M. Brożek, Źródła do..., s. 84.

27 Zob. P. Watson, Praecepta Amoris. Ovid's Didactic Elegy, w: Brill's Companion to Ovid, ed. by B.W. Boyd, Leiden 2002, s. 151-165.

28 Zob. R.K. Gibson, The "Ars amatoria", w: A Companion to Ovid, ed. by P. Knox, Malden-Oxford 2009, s. 92.

29 Zob. P.L. Allen, "Ars amandi, ars legendi"..., s. 183. 
i rudymentów języka łacińskiego. Jeden ze starszych rękopisów ${ }^{30}$ zawiera łacińskie i walijskie glosy do pierwszej księgi poematu. Znajdujące się w nich wskazówki dotyczą kolejności wyrazów w zdaniu, definiują części mowy, przybliżają etymologię i znaczenie trudniejszych wyrazów. Kodeks służył najprawdopodobniej jako szkolny podręcznik wykorzystywany na wstępnym etapie nauczania łaciny ${ }^{31}$.

W przypadku Pseudo-Ars amatoria kod kulturowy oraz źródła szaty gramatyczno-retorycznej, za którą kryła się interpretacja, były łatwo rozpoznawalne. Najwymowniejszym świadectwem jest przypisanie autorstwa antycznemu poecie, odnotowane w szeregu rękopisów. Innymi słowy, dla średniowiecznych kopistów utwór zawierał dość elementów znaczeniowych mieszczących się w zbiorze argumentów, dla których wspólną wartością była postać Owidiusza postrzegana w dwóch kategoriach: dydaktyzmu i miłości ${ }^{32}$. Taka atrybucja pozwoliła na włączenie tekstu w kanon lektur szkolnych, gdyż, zgodnie z wypracowaną wtedy koncepcją autorstwa, gwarantowała jego autorytatywność i wiarygodność (auctoritas) ${ }^{33}$. Uznawano, że dzieło jest warte powielania i imitacji, podobnie jak Ars amatoria, którą anonimowy poeta naśladował.

Przez wybór tematyki oraz dystychu elegijnego jako formy metrycznej poeta odsłaniał przed czytelnikami źródła literackich inspiracji. Pierwszy wers „Si quem forte iuvat subdi sapienter amori / sic

${ }^{30}$ Heinsius Oxoniensis, IX wiek, Oxford, Bodleian Library, Auct. F.4.32, k. 37r.-47r.

31 Zob. R.J. Hexter, Ovid and Medieval Schooling. Studies in Medieval School Commentaries on Ovid's "Ars Amatoria", "Epistulae Ex Ponto", and "Epistulae Heroidum", München 1986, s. 32. Szersze omówienie zawartości komentarza w idem, Sex Education. Ovidian Erotodidactic in the Classroom, w: The Art of Love..., s. 304-306.

${ }^{32}$ Jak zauważył Umberto Eco, średniowieczni traktowali autora jako synekdochę bądź uosobienie określonej tradycji literackiej, zob. U. Eco, Tipologia della falsificazione, w: Fälschungen im Mittelalter. Internationaler Kongreß der Monumenta Germaniae Historica München, 16.-19. September 1986, 1. Teil: Kongreßdaten und Festvorträge; Literatur und Fälschung, Hannover 1988, s. 75.

${ }_{33}$ Zob. M.-D. Chenu, "Auctor, actor, autor", „Archivium Latinitatis Medii Aevi” 3 (1927), s. 81-86, oraz A. Minnis, Medieval Theory..., s. 73-117. 
amet incipiens, ut mea musa docet" [Jeśli się komuś podoba ulec mądrze miłości, niech zacznie kochać tak, jak uczy moja muza] jest echem słów otwierających Ars amatoria: „Siquis in hoc artem populo non novit amandi / hoc legat et lecto carmine doctus amet" (I 1-2) ${ }^{34}$. Już na wstępie określono fundamentalną dla poematu dydaktycznego triadę: odbiorcą jest każdy, kto pragnie poznać sztukę miłości, nauczycielem - uczony poeta, zaś przedmiotem wykładu - miłość.

W rzeczywistości grono adresatów było węższe - kobiety, jak we wszystkich ówczesnych podręcznikach miłości, sprowadzano do roli przedmiotu zalotów. Ich uprzedmiotowienie jest dostrzegalne w samej strukturze traktatów, które choć wierne tokowi Owidiuszowego wywodu, naśladowały jedynie dwie pierwsze księgi Ars amatoria; trzecia, zawierająca zalecenia dla pań, stawiająca je w roli odbiorczyń, była skrupulatnie pomijana, jej miejsce zajmowały mizoginiczne Remedia ${ }^{35}$.

Po zaleceniach dotyczących właściwego doboru kochanki wykład Pseudo-Ars amatoria jest powtórzeniem wskazówek antycznego poety, jak i gdzie znaleźć kobietę (w. 21-24) ${ }^{36}$. Młodzieniec powinien chodzić w miejsca, które zwykła odwiedzać, by tam zastawić sieci i szukać okazji do nawiązania kontaktu (w. 30-38) ${ }^{37}$. W tym

34 „Komu sztuka miłości nie jest u nas znana, / niechaj czyta i wdraża w życie me nauki”. Tekst polski za: Owidiusz, Sztuka kochania, przeł. E. Skwara, Wrocław 2016. Cytaty łacińskie za L’art d’aimer, texte établi et traduit par H. Bornecque, Paris 1994. Dalej dla oznaczenia utworu używany będzie skrót $A A$.

35 Zob. A. Bisanti, Gli "Pseudo-Remedia amoris" fra riscrittura ovidiana e tematica misogina, „Studi Medievali” 54 (2013), s. 851-903, idem, Un “falso” ovidiano del XIII secolo: gli "Pseudo-Remedia amoris", w: Falso e falsi. Prospettive teoriche e proposte di analisi, a cura di. L. Scalabroni, Pisa 2010, s. 261-270. Z lektury accessus wynika, że również antyczny poemat czytano wyłącznie dla dwóch pierwszych ksiąg: „Modus istius operis talis est, ostendere quo modo puella possit inveniri, inventa exorari, exorata retineri”, Accessus ad auctores..., s. 33; „Sposób przeprowadzenia utworu jest taki: pokazanie, jak można dziewczynę znaleźć, znalezioną uprosić, uproszoną zatrzymać przy sobie”, M. Brożek, Źródła do..., s. 84.

36 Zob. $A A$, I $35-44$.
37 Zob. $A A$, I $45-50$. 
celu należy poznać piastunkę (nuncia), która w zamian za podarunki przedstawi prośby kochanka (w. 39-44) ${ }^{38}$.

Kobiety przedstawiono zgodnie z Owidiuszowymi loci comunes: choć początkowo niechętne, ze względu na swoją naturę zawsze ulegają namowom (w. 69) ${ }^{39}$, dlatego warunkiem niezbędnym do podbicia ich serc jest wytrwałość, którą obrazuje znane porównanie do kropli drążącej skałę (w. 66): „Ferrea congeries dirumpitur improbitate / et durum lapidem gutta cadendo cavat" [Żelazna bryła pęka dzięki zawziętości / i twardą skałę kropla drąży padaniem] $]^{40}$.

Ostatnim etapem znajomości jest cielesne zbliżenie z kobietą. Nauczyciel radzi, by z pomocą pośredniczki znaleźć dogodne miejsce, spotkać się na osobności z ukochaną i dopełnić, najczęściej wbrew jej woli, aktu miłosnego. Wersy 141-172 są szczegółowym opisem stosunku, który w dosłowności i realizmie oddala się od Owidiuszowego modelu (AA, II 701-740). Obraz podporządkowano męskiemu punktowi widzenia; stosunek seksualny jest ukoronowaniem zalotów i świadczy o wartości kochanka. Jego wcześniejsze starania pójdą jednak na marne, jeśli nie zdoła zatrzymać kobiety przy sobie, o czym traktują ostatnie zalecenia odpowiadające tematyce drugiej księgi Ars amatoria.

Otwiera je dwuwierszowy prolog, w którym wyraźnie zaznaczono zmianę tematyki (w. 173-174): „Arte mea si quis sibi consociabit amicam, / vatis opem querat, qua foveatur amor" [Jeśli ktoś dzięki mojej sztuce złączy się z przyjaciółką, / niech pozna sposoby poety, jak pielęgnować miłość], nawiązujący do początkowych wersów drugiej księgi starożytnego poematu (AA, II 12): ,,arte mea capta est, arte tenenda mea est” [„,z mą sztuką ją złapałeś, z mą sztuką zatrzymasz"]. Najskuteczniejszymi środkami perswazji są ciepłe słowa,

38 Zob. $A A$, I $367-372$.

39 Zob. $A A$, I 273-274.

40 Zob. AA, I 473-474: „Quid magis est saxo durum, quid mollius unda? / Dura tamen molli saxa cavantur aqua” [„Cóż jest miększe niż woda, twardsze niż opoka? / Lecz twardą skałę skruszą miękkiej wody deszcze”]. 
dyskrecja i regularne współżycie, o ile poprzedzone sutym posiłkiem i odpowiednią ilością wina, ten zaś, kto mimo rad nie zdoła zatrzymać ukochanej, będzie cierpiał z własnej winy (w. 189-190).

Istotną zmianą $\mathrm{w}$ stosunku do literackiego modelu jest umieszczenie sceny współżycia w centralnym punkcie wykładu, w partii odpowiadającej tematycznie pierwszej księdze Ars amatoria, podczas gdy analogiczny opis zajmuje końcowe fragmenty jej księgi drugiej. Podkreślono w ten sposób klimaks zawarty w schemacie gradus amoris, przedstawiając młodym odbiorcom kontakt cielesny z kobietą, czy raczej gwałt (vis), jako kluczowy etap erotycznej przygody (w. 165-168): „Vim faciat iuvenis, quamvis nimis illa repugnet / nam si desistat, mente puella dolet. / Expectat pocius luctando femina vinci, / quam velit, ut meretrix, crimina sponte pati” [Niech siłą ją weźmie młodzieniec, choćby bardzo walczyła, / bo dziewczyna, jeśli się opiera, w duszy cierpi. / Kobieta, walcząc, spodziewa się raczej, że zostanie pokonana, / niż pragnie, jak prostytutka, dobrowolnie grzeszyć].

Za czytelnym nawiązaniem do wizji kobiecości proponowanej przez Owidiusza, zgodnie z którą kobieta szczęśliwa to kobieta zmuszona siłą do współżycia ( $A A$, I 673-678), kryje się propagowanie postawy trudnej do pogodzenia $\mathrm{z}$ etycznym wymiarem dzieła. Tymczasem podobne wzmianki o scenach gwałtu były powszechne w innych tekstach szkolnych, począwszy od omawianych przez antycznych gramatyków Kontrowersji Seneki po średniowiecznego Pamphilusa - przypisywaną Owidiuszowi komedię elegijną. Zdaniem Marjorie Woods podobne opisy służyły określonym celom dydaktycznym: działały stymulująco na uczniów, chętniej zapamiętujących trafiające do ich wyobraźni sceny, przekazywały podstawowe wyobrażenia dotyczące konwencjonalnego podziału ról społecznych między płciami, pomagały w nabyciu świadomości własnej męskości i dojrzałości oraz związanej z nią władzy ${ }^{41}$.

41 M.C. Woods, Rape and the Pedagogical Rhetoric of Sexual Violence, w: Criticism and Dissent in the Middle Ages, ed. by R. Copeland, Cambridge 1996, s. $56-86$. 
Młodzieńcy otrzymywali w formie Pseudo-Ars amatoria podręcznik miłości dwornej, którego aspekt dydaktyczny zasadzał się na zespole tematycznych i strukturalnych nawiązań do modeli literackich. Traktat mógł być uznany za tekst szkolny, ponieważ, będąc rodzajem abbreviatio, dzielił ze Sztuka kochania schemat kompozycyjny i formę elegii dydaktycznej na tyle czytelnie, że jego autorstwo przypisano Owidiuszowi. Treść zaleceń zaktualizowano, przenosząc niepokoje kochanków w epokę średniowiecza i przyjmując za nowy literacki paradygmat miłość dworną, sprowadzoną do konwencjonalnych motywów. Pseudo-Ars amatoria jawiła się zatem jako tekst przesiąknięty fikcją i jako taki znakomicie poddający się procesowi dekonstrukcji opisanemu przez Allena. Lektura mogła prowadzić do przekazania wybranych modeli społecznych zachowań, niewątpliwie jednak jej prymarnym celem było pobudzenie wyobraźni i rozwinięcie możliwości twórczych czytelników.

\section{Rola dydaktyczna Pseudo-Ars amatoria w Akademii Krakowskiej}

Ślady wykorzystywania traktatu w Akademii Krakowskiej prowadzą rozważania we wskazanym wyżej kierunku. Wszystkie trzy krakowskie rękopisy (BJ 2035, BJ 2115, BJ 2233) są papierowymi klockami in quarto, złożonymi w drugiej połowie XV wieku. Układ tekstu $\mathrm{w}$ pojedynczych kolumnach $\mathrm{z}$ szerokimi marginesami przeznaczonymi na komentarze (obecne w kodeksie BJ 2115), rubrykowanie ograniczone do inicjałów i akapitów, wyróżnienia sentencjonalnych dystychów świadczą o powstaniu i wykorzystaniu kodeksów w środowisku szkolnym.

W rękopisie BJ 2035 przekazano obie wersje Facetusa i Disticha Catonis. Kodeks BJ 2233 - oprócz popularnych utworów przypisywanych Owidiuszowi: De anulo, De pulice, De lupo, De nuntio sagaci - zawiera bajki Awiana, Pauper Henricus Henryka z Settimello, 
Doligamusa Adolfa z Wiednia, De Piramo et Thisbe przypisywane Tyderykowi, satyrę zwierzęcą Asinarius, fragmenty De planctu naturae Alana z Lille oraz znany w całej Europie planctus nad upadkiem Troi Pergama flere volo ${ }^{42}$. Podobnie kodeks BJ 2115 obok De consolatione philosophiae Boecjusza zawiera tę samą wersję De Piramo et Thisbe, pseudoowidianum De pulice, a także komedię elegijną Geta Witalisa z Blois, Ilias Latina i anonimowy wiersz o wiktorii Grunwaldzkiej (inc. „Anno milleno quadringentesimo deno”) ${ }^{43}$.

Wymienione teksty obok opisanego wyżej Liber Catonianus stanowiły podstawowy zestaw lektur na wstępnym etapie nauczania, czego dowodzą zachowane kopie pochodzące ze środowisk klasztornych i katedralnych ${ }^{44}$. Jak zdradzają noty proweniencyjne wewnątrz kodeksu BJ 2115, należał on do kanonika poznańskiego Stanisława z Dobieszewa, a pierwsze składki zawierające dzieło Boecjusza zostały spisane w poznańskiej szkole katedralnej. Być może rękopis trafił do Krakowa wraz z właścicielem, immatrykulowanym w 1442 roku, w tym samym, w którym zakończono przepisywanie traktatu, jak zdradza explicit: „Finis Ovidii Sine titulo 1442” (k. 542) ${ }^{45}$.

Zniszczony w czasie II wojny światowej kodeks Jana ze Słupcy powstał w nieokreślonym ośrodku klasztornym. Wydane przez Aleksandra Brücknera polskie glosy marginalne są świadectwem lektury tekstów podczas nauki łacińskiej gramatyki i składni ${ }^{46}$. W podob-

42 Opis katalogowy w Catalogus codicum manuscriptorum Bibliothecae Universitatis Jagellonicae Cracoviensis, ed. W. Wisłocki, Cracoviae 1877-1881, s. 535-536.

43 Ibidem, s. 510-511.

44 Zob. K. Stopka, Szkoły katedralne metropolii gnieźnieńskiej w średniowieczu. Studia nad kształceniem kleru polskiego w wiekach średnich, Kraków 1994, s. 136146; idem, Zakres i program nauczania septem artes $w$ szkołach katedralnych, w: Septem artes $w$ ksztaltowaniu..., s. 125-136.

${ }_{45}$ Zob. Metryka Uniwersytetu Krakowskiego z lat 1400-1508, wyd. A. Gąsiorowski, T. Jurek, I. Skierska, t. 1, Kraków 2004, s. 193.

46 Zob. A. Brückner, Średniowieczna poezya..., s. 304-372; zob. także: J. Kaliszuk, Codices deperditi. Średniowieczne rękopisy łacińskie Biblioteki Narodowej utracone w czasie II wojny światowej. Dzieje i charakterystyka kolekcji, t. 1, Wrocław 2016, s. 449-450. 
nym celu sięgnięto po Pseudo-Ars amatoria w kodeksie BJ 2035: początkowe sześćdziesiąt wersów zostało opatrzone cyframi, które wskazywały logiczną kolejność wyrazów w zdaniu, oraz glosami interlinearnymi zawierającymi synonimy i objaśnienia trudniejszych do zrozumienia słów.

O ile użyteczność podobnych tekstów można łatwo wyjaśnić na poziomie kształcenia parafialnego czy klasztornego, o tyle wątpliwości wzbudza ich wykorzystanie jako podręczników do nauki języka na etapie uniwersyteckim. Częściowym wyjaśnieniem jest stosunkowo niski poziom znajomości łaciny u świeżo immatrykulowanych żaków, na co mógłby wskazywać wspomniany explicit w kodeksie BJ 2115, powstały w pierwszym roku studiów Stanisława z Dobiesze$\mathrm{wa}^{47}$. Ci, którzy opanowali podstawy języka, wykorzystywali Pseudo-Ars amatoria w innych celach.

De consolatione philosophiae Boecjusza oraz De planctu naturae Alana z Lille, zapisane w dwóch krakowskich kodeksach, zaliczono w skład lektur przewidzianych statutami kolegiatury fundowanej w 1420 roku przez Katarzynę Mężykową, małżonkę wojewody ruskiego Jana Mężyka:

Tercio Collegiatus Domine Manzikonisse iuxta suam institucionem legat in Poesi libros infra deputatos videlit: Boecium de Consolacione, Alanum de planctu nature, Valerium Maximum, Libros Vergilii, Ovidii, Oracii, Terencii, Stacii ${ }^{48}$.

47 Tak Marjorie C. Woods wyjaśnia obecność w bibliotekach środkowoeuropejskich uniwersytetów utworów, które na zachodzie Europy wykorzystywano w początkowych etapach kształcenia, M.C. Woods, Using the Poetria nova to Teach Dictamen in Italy and Central Europe, w: Papers on Rhetoric. V. Atti del Convegno Internazionale "Dictamen, Poetria and Cicero: Coherence and Diversification" (Bologna, 10-11 maggio 2002), ed. by L. Calboli Montefusco, Roma 2003, s. 263-264.

48 Tekst łaciński za: J. Szujski, Założenie i urządzenie Collegii Minoris, „Archiwum do Dziejów Literatury i Oświaty w Polsce” Seria I, 1 (1878), s. 97. Na temat fundacji Katarzyny Mężykowej zob. S. Kuraś, Fundacja kolegiatury epistolografii i sztuki pisania dokumentów w Akademii Krakowskiej w r. 1420, „Małopolskie Studia Historyczne" 6 (1964), s. 119-123. 
[Po trzecie: kolegiat pani Mężykowej zgodnie ze swoim stanowiskiem ma czytać z poezji wskazane niżej księgi, czyli Boecjusza O pocieszeniu, Alana z Lille Skarge natury, Waleriusza Maksymusa, dzieła Wergiliusza, Owidiusza, Terencjusza, Stacjusza].

W statucie z 1476 roku przewidziano uzupełnienie listy lektur o „Plauti Comedias aut alia Poetica” ${ }^{49}$, wśród których mogły się znaleźć również utwory średniowieczne. Dzięki inicjatywie Mężykowej oraz fundacji podskarbiego królewskiego Tomasza Nowki (obsadzonej mniej więcej w latach 1419-1422) w Akademii Krakowskiej powstały pierwsze prywatne katedry gramatyki i retoryki. Ich celem było przekazanie, głównie studentom pochodzącym z uboższych rodzin, podstaw redakcji łacińskich dokumentów i przygotowanie ich do zawodu notariuszy. Jak stanowił akt fundacyjny katedry Katarzyny Mężykowej:

Et primo voluit, quod predictus collegiatus legat et exercitet diebus legibilibus unum actum peragendo, videlicet in libris gramaticalibus seu poeticalibus, prout processerit de voluntate magistrorum et presertim collegiatorum promotorum, declinando, construendo et legendo, aut docendo in rethorica epistolas missiles, aut formas privilegiorum fideliter et efficaciter instruendo ${ }^{50}$.

[Przede wszystkim pragnęła, by wspomniany kolegiat czytał i prowadził w dni wskazane do zajęć ćwiczenia z jednej dziedziny, mianowicie gramatyki bądź retoryki, by przy tym postępował wedle woli magistrów, a zwłaszcza promotorów kolegiów, odmieniając przez przypadki, konstruując zdania, czytając albo ucząc podczas zajęć retoryki układania listów bądź pokazując uczciwie i skutecznie, jak pisać przywileje].

Faktycznym przedmiotem wykładu była zatem ars dictaminis (od dictare - dyktować, ale i układać tekst), która, początkowo znana jako sztuka pisania dokumentów, z czasem zaczęła być interpreto-

49 Codex diplomaticus Universitatis Studii Generalis Cracoviensis, Cracoviae 1880 , t. 3 , s. 47.

50 Cyt. za: S. Kuraś, Fundacja kolegiatury..., s. 121. 
wana szerzej, jako sztuka kompozycji tekstów w języku łacińskim ${ }^{51}$. Wzorce czerpano ze zbiorów istniejących dokumentów (formularzy) oraz wspomnianych wyżej utworów literackich.

Przykładem typowego kodeksu odpowiadającego programowi nauczania przedstawionemu w statutach jest ten o sygnaturze BJ 2458. Obok kanonicznego zestawu autorów szkolnych (Pamphilus, Pauper Henricus, satyry Juwenalisa, fragmenty Remedia amoris) zawiera wybór wzorcowych listów, dwie pierwsze księgi Listów $z$ Pontu Owidiusza oraz Rota Veneris Boncompagna da Signa $(\mathrm{zm} . \mathrm{w} 1250 \mathrm{r} \text {. })^{52}$. Ostatni tekst autorstwa mistrza retoryki w bolońskiej alma mater w znacznej części poświęcony był epistolarnym salutationes - zwrotom do adresatów, w tym przypadku płci żeńskiej. Po omówieniu różnych rodzajów pozdrowień, odpowiednich do pochodzenia i pozycji społecznej korespondentów, przywołano dłuższe wypowiedzi wraz ze wskazaniem figur retorycznych i gotowych do wykorzystania formuł; ostatnią część traktatu poświęcono mowie ciała - gestom i westchnieniom, za pomocą których komunikują się zakochani ${ }^{53}$. Przykład Rota Veneris pokazuje, jak literackie konwencje poezji miłosnej stały się narzędziem w rękach nauczyciela retoryki. Boncompagno stworzył podręcznik epistolografii i sztuki kochania, dając znakomity dowód potencjału dydaktycznego tkwiącego $\mathrm{w}$ średniowiecznej ars amatoria.

51 Na temat ewolucji i znajomości ars dictaminis w krakowskim uniwersytecie zob. T. Michałowska, Średniowieczna teoria literatury w Polsce. Rekonesans, Wrocław 2007, s. 146-182.

52 Catalogus codicum manuscriptorum..., s. 588.

53 Podstawowe informacje biograficzne na temat Boncompagna podaje C.A.L.M.A. Compendium Auctorum Latinorum Medii Aevi (500-1500), t. 2, a cura di M. Lapidge, C. Leonardi, Firenze 2000, s. 471. Pierwszą naukową edycję tekstu opracował Ryszard Ganszyniec, Polskie listy miłosne dawnych czasów, Lwów 1925, s. 171-183. Nowsze wydanie oparto na faksymile piętnastowiecznego inkunabułu, Rota Veneris, a cura di P. Garbini, Roma 1996, s. 28-88. Więcej na temat traktatu zob. E. Ruhe, „De amasio ad amasiam“: Zur Gattungsgeschichte des mittelalterlichen Liebesbriefes, München 1975, s. 127-150. 
Do podstawowych zagadnień poruszanych w podręcznikach należały części struktury listu (salutatio, exordium, narratio, petitio, conclusio) oraz colores rhetoricae dotyczące warstwy stylistycznej. W przypadku anonimowej Sztuki kochania rozmowy piastunki, kochanka i kobiety obejmują sześćdziesiąt cztery wersy, czyli ponad jedną trzecią całości, a centralne miejsce dialogu w kompozycji utworu podkreślają komentarze znajdujące się na marginesach rękopisów. W spisie treści jednego z najstarszych kodeksów przekazujących tekst zanotowano "Item poeta de arte procandi anathema sit legendum”" ${ }^{4}$. Słownik Du Cange’a definiuje procare za pomocą synonimu poscere, cytując hasło zawarte w średniowiecznym glosariuszu: „Procare, demandar, Prov. poscere, postulare, proprie mulierum, ut Procio, procax, mulierum petitor. Procacitus, petitor, demandador, Prov. Procaculus, dimin. idem"55. Przez wybór tytułu anonimowy skryba sprowadził znaczenie przepisywanego tekstu do starań o względy kobiety, do petitio wyrażonej w prośbach młodzieńca i służącej. Podobnie postąpił czytelnik kodeksu Jana ze Słupcy, zamieszczając uwagę na marginesie (jedyną) dotyczącą treści: precaria proszba ${ }^{56}$.

O roli traktatu w nauczaniu sztuki pisania listów wyraźnie świadczy formularz związany z kancelarią królewską Władysława Jagiełły, przechowywany do II wojny światowej w bibliotece uniwersytetu w Królewcu (sygn. 1555), w której obok listów i pism urzędowych zgromadzono kilka utworów literackich, wśród nich „Ovidius metricus de arte amandi et ludo mulierum, metricus totus” (k. 265-268), czyli Pseudo-Ars amatoria oraz fragmenty Pseudo-Remediów ${ }^{57}$. Sam

54 München, Staatsbibliothek, Clm. 11601, k. 241r., cyt. za: E.J. Thiel, Mittellateinische Nachdichtungen..., s. 117.

55 Glossarium mediae et infimae latinitatis, éd. par Ch. du Fresne Du Cange, augm. L. Favre, Graz 1883-1887, t. 6, kol. 514b.

56 A. Brückner, Średniowieczna poezya..., s. 320.

57 Szczegółowy opis kodeksu w: B. Ulanowski, Liber formularum ad ius Polonicum necnon canonicum spectantium in codice Regiomontano asservatarum, t. 1, Cracoviae 1895, s. 169-203. 
rękopis służył najprawdopodobniej jako pomoc w sporządzaniu dokumentów i listów ${ }^{58}$.

Więcej szczegółów zawierają glosy umieszczone na marginesach tekstu w kodeksie BJ 2115. Ich celem było ułatwienie orientacji w strukturze traktatu przez podanie zwięzłych parafraz do kolejnych części tematycznych. Wszystkie zapisano w drugiej osobie liczby pojedynczej, podkreślając edukacyjny aspekt podręcznika miłości. Komentarze do wersów 75-76 informują o okolicznościach rozmowy zakochanych: „Si consistant multi curiales coram tuam dominam et tu uenias in medium eorum sic loquare ei" [Jeśli wielu dworzan stanęło w poblizzu twojej ukochanej, a ty wchodzisz między nich, tak do niej przemów] (k. 534). Dialog otwiera salutatio w stylu wysokim, zgodnie z konwencjami poezji dwornej, w której kobieta zajmuje uprzywilejowaną pozycję (w. 79-80): „Stella serena nitens, facie rutilante decora, / ecce tuum famulum nunc paciare loqui" [Pogodna gwiazdo lśniąca, jaśniejąca złocistym obliczem, / zechciej dopuścić do głosu twego sługę]. W myśl zaleceń ars dictaminis następne wersy tworzą exordium (w. 81-82): „Si tibi nobilitas, probitas et forma decora / laudetur velud est, par tibi nulla manet" [Jeśli sławiono by twą szlachetność, czystość i piękno takimi, jakie są, żadna tobie nie będzie równa], opatrzone uwagą na marginesie: „Sic tuam dominam laudibus commendabis" [Tak będziesz sławił pochwałami swoją panią] (k. 535). Opis piękna kobiety odpowiada partii narratio; komentarz ograniczono do wyliczenia opisywanych części ciała: (w. 85-100) „sic lauda crines frontem nucam ut sequitur" [tak pochwal włosy, czoło, szyję, jak poniżej], „oculos, genas, nasus, labra, dentes” [oczy, policzki, nos, usta, zęby], „de risu qui ab ore ipsius pervenit” [o śmiechu, który dochodzi z jej ust], „hec exteriora indicant te ita eam penitus dispositam" [wygląd zdradzi ci, jak zbudowane ma wnętrze], „de dispositione et pulcritudine mamillarum" [o kształcie i pięknie

58 Zob. K. Ożóg, Uczeni w monarchii Jadwigi Andegaweńskiej i Władysława Jagiełly (1384-1434), Kraków 2004, s. 154-155. 
piersi]. Przemowę młodzieńca kończy petitio i conclusio, w których prosi o względy wybranki (w. 109-112):

Si me conspicies vel me digneris amare, / gaudeo plus quam si quis mihi regna daret. / Deprecor hoc tantum: famulus fatearis amandum, / ut per te vivat, vita salusque mea.

[Jeśli na mnie spojrzysz albo zechcesz pokochać, / ucieszę się bardziej, niż gdyby ktoś królestwa mi oddawał. / Błagam tylko o to: wyznaj, że sługa jest godzien kochania, / by dzięki tobie żył, życie i zbawienie moje].

Wymienione sformułowania są przykładem descriptio puellae topiki przedstawiania kobiecej urody, wzorów dostarczały tu najpoczytniejsze podręczniki sztuki poetyckiej ${ }^{59}$. W partiach ars dictaminis poświęconych listom miłosnym zalecano stosowanie podobnych formuł jako colores rhetoricae, stąd, zgodnie z konwencją, opis wybranki rozpoczęto od głowy, podkreślając piękno włosów, następnie twarzy, kończąc na znajdujących się niżej partiach ciała; zwrócono uwagę na szlachetne pochodzenie, wykorzystano epitety podkreślające blask bijący z jej postaci.

W tym samym czasie, gdy w krakowskim uniwersytecie czytano Pseudo-Ars amatoria, powstała anonimowa Epistola ad dominicellam. O jej związkach z Krakowem świadczą polskie wtręty w tekście i wzmianka o miejscu zamieszkania ukochanej ${ }^{60}$. Część dotycząca opisu kobiecej urody zawiera stały zestaw epitetów i apostrof:

Cutis tua candescit, ut lilium albescit.

Moribus imbuta

59 Mateusz z Vendôme, Ars versificatoria, I 56, w: E. Faral, Les arts poétiques..., s. 129; Godfryd z Visnauf, Poetria Nova, 562-599, w: E. Faral, Les arts poétiques..., s. 214-215.

60 Zob. M. Włodarski, Średniowieczna poezja łacińska w Polsce, Wrocław 2007, s. XCVII-CI. To tylko jeden $\mathrm{z}$ wielu listów miłosnych łączonych z krakowskim środowiskiem uniwersyteckim, por. T. Michałowska, Epistola amatoria, w: eadem, Literatura polskiego średniowiecza. Leksykon, Warszawa 2011, s. 233-238. 
virescis ut ruta.

Clarescis ut stella,

o virgo tenella.

Digitos habes tenues, manus vero carnosas:

eburneos dentes, capillos splendentes.

[Twa płeć, przedziwnie biała / blaskiem lilii pała. / W każdej swej zalecie / kwitniesz, niby kwiecie, / lśnisz, jak gwiazda świetna. / Panienko szlachetna. / Paluszki masz pieszczone, / ramiona toczone; / ząbki z kości słoniowej, / złotą włosów koronę $e^{] 61}$.

List ad dominicellam należy uznać za owoc lektury podręczników dyktamenu oraz uważnego naśladownictwa wzorów - wśród nich być może Pseudo-Ars amatoria. Modelowy charakter traktatu wynikał z kilku czynników. Krakowscy mistrzowie i studenci, wchodząc w kontakt $\mathrm{z}$ tekstem, odnosili go do zespołu wyobrażeń opartych na bagażu czytelniczych doświadczeń. Tematyka osadzona w konwencjach literatury dwornej oraz tradycji poematów dydaktycznych pozwalała widzieć w nim utwór szkolny, odpowiedni jako materiał do teoretycznych rozważań nad strukturą listów miłosnych. Intertekstualne związki z antycznym modelem przyczyniły się do ugruntowania pozycji tekstu w kanonie lektur.

\section{Podsumowanie}

Zapoznając młodych czytelników z opisem konwencjonalnych zachowań miłosnych, pobudzano ich wyobraźnię i uczono formułowania myśli w języku łacińskim z zastosowaniem podobnych do tych

61 Epistola ad dominicellam, strofy 27-29, przeł. J. Jedlicz, w: Antologia poezji łacińskiej w Polsce. Średniowiecze, red. K. Liman, Poznań 2004, s. 571-573. Tam też tekst łaciński za: R. Ganszyniec, Polskie listy..., s. 61-65. 
w opisie figur i wyrażeń. Jak wynika z kontekstu, w jakim utwór został przekazany w omówionych rękopisach, oraz $\mathrm{z}$ informacji zawartych w towarzyszących mu komentarzach i glosach, na przykładzie anonimowej ars amandi przekazywano początkującym studentom podstawy języka łacińskiego, a tym, którzy poznali zasady gramatyki i składni, objaśniano reguły kompozycji. W krakowskiej wszechnicy, podobnie jak w uniwersytetach i szkołach średniowiecznej Europy, sztukę kochania podporządkowano sztuce dyktamenu.

\section{Bibliografia}

Accessus ad auctores: Bernard d'Utrecht, Conrad d'Hirsau. «Dialogus super auctores», éd. critique, entièrement revue et augmentée par R.B.C. Huygens, Leiden 1970. Allen P.L., "Ars amandi, ars legendi". Love Poetry and Literary Theory in Ovid, Andreas Capellanus and Jean de Meun, „Exemplaria” 1 (1989) s. 181-205.

Allen P.L., The Art of Love. Amatory Fiction from Ovid to the 'Romance of the Rose', Philadelphia 1992.

Antologia poezji łacińskiej w Polsce. Średniowiecze, red. K. Liman, Poznań 2004.

Bisanti A., Un "falso" ovidiano del XIII secolo: gli "Pseudo-Remedia amoris", w: Falso e falsi. Prospettive teoriche e proposte di analisi, a cura di L. Scalabroni, Pisa 2010, s. 261-270.

Bisanti A., Gli "Pseudo-Remedia amoris" fra riscrittura ovidiana e tematica misogina, „Studi Medievali” 54 (2013), s. 851-903.

Boas M., De librorum catonianorum historia atque compositione, „Mnemosyne” 42 (1914), s. 17-46.

Boncompagno da Signa, Rota Veneris, a cura di P. Garbini, Roma 1996.

Brożek M., Źródła do średniowiecznej teorii wykładu literatury, Warszawa 1989.

Brückner A., Średniowieczna poezya łacińska w Polsce [cz. 1], „Rozprawy Akademii Umiejętności. Wydział Filologiczny" 16 (1892), s. 304-372.

C.A.L.M.A. Compendium Auctorum Latinorum Medii Aevi (500-1500), a cura di M. Lapidge, C. Leonardi, Firenze 2000.

Catalogus codicum manuscriptorum Bibliothecae Universitatis Jagellonicae Cracoviensis, ed. W. Wisłocki, Cracoviae 1877-1881.

Chenu M.-D., "Auctor, actor, autor”, „Archivium Latinitatis Medii Aevi” 3 (1927), s. $81-86$.

Cherchi P., Andreas' "De amore": Its Unity and Polemical Origin, w: idem, Andrea Cappellano, i trovatori e altri temi romanzi (Biblioteca di Cultura, 128), Roma 1979, s. 83-111. 
Codex diplomaticus Universitatis Studii Generalis Cracoviensis, Cracoviae 1880.

Curtius E.R., Literatura europejska i łacińskie średniowiecze, przeł. A. Borowski, Kraków 2009.

Dąbrówka A., Treści religijne w podręcznikach i lekturach szkolnych, w: Animarum cultura. Studia nad kultura religijna na ziemiach polskich w średniowieczu, red. H. Manikowska, W. Brojer, Warszawa 2008, s. 459-498.

Don Monson A., Andreas Capellanus, Scholasticism, and the Courtly Tradition, Washington 2005.

Dronke P., Pseudo-Ovid, Facetus, and the Arts of Love, „Mittellateinisches Jahrbuch” 11 (1976), s. 126-131.

Dybeł K., Entre la connaissance et l'amour : le regard dans l'univers romanesque de Chrétien de Troyes, Cracovie 2012.

Eco U., Tipologia della falsificazione, w: Fälschungen im Mittelalter. Internationaler Kongreß der Monumenta Germaniae Historica München, 16.-19. September 1986, 1. Teil: Kongreßdaten und Festvorträge; Literatur und Fälschung, Hannover 1988, s. 69-82.

Faral E., Les arts poétiques du XII et du XIII siècle. Recherches et documents sur la technique littéraire du Moyen Âge, Paris 1962.

Friedman L.J., Gradus amoris, „Romance Philology” 19 (1965/66), s. 167-177.

Ganszyniec R., Polskie listy miłosne dawnych czasów, Lwów 1925.

Gibson R.K., The "Ars amatoria", w: A Companion to Ovid, ed. by P. Knox, MaldenOxford 2009, s. 90-103.

Glauche G., Schullektüre im Mittelalter. Entstehung und Wandlungen des Lektürekanons bis 1200 nach den Quellen dargestellt, Münich 1970.

Glossarium mediae et infimae latinitatis, éd. par Ch. du Fresne Du Cange, augm. L. Favre, Graz 1883-1887.

Grammatici Latini, ed. H. Keil, t. 7, Lipsiae 1880.

Hexter R.J., Ovid and Medieval Schooling. Studies in Medieval School Commentaries on Ovid's "Ars Amatoria", "Epistulae Ex Ponto", and "Epistulae Heroidum", München 1986.

Hexter R.J., Sex Education. Ovidian Erotodidactic in the Classroom, w: The Art of Love. Bimillennial Essays on Ovid's "Ars Amatoria" and "Remedia Amoris", ed. by R. Gibson, S. Green, A. Sharrock, Oxford 2007, s. 298-317.

Hexter R.J., Shades of Ovid. Pseudo- (and para-) Ovidiana in the Middle Ages, w: Ovid in the Middle Ages, ed. by J.G. Clark, F.T. Coulson, K.L. McKinley, Cambridge 2011, s. 284-309.

Jauss R., Historia literatury jako prowokacja dla nauki o literaturze, w: idem, Historia literatury jako prowokacja, przeł. M. Łukasiewicz, Warszawa 1999, s. 126-180.

Kaliszuk J., Codices deperditi. Średniowieczne rękopisy łacińskie Biblioteki Narodowej utracone w czasie II wojny światowej. Dzieje i charakterystyka kolekcji, Wroclaw 2016. 
Kuraś S., Fundacja kolegiatury epistolografii i sztuki pisania dokumentów w Akademii Krakowskiej w r. 1420, „Małopolskie Studia Historyczne” 6 (1964), s. 119-123. Lehmann P., Pseudo-Antike Literatur des Mittelalters, Darmstadt 1964.

Libri formularum saeculi XVmi, ed. B. Ulanowski, „Starodawne Prawa Polskiego Pomniki" 10 (1888), cz. 1.

Maciag A., Jaki pożytek plynie z czytania? Kwestia utilitas w średniowiecznych accessus ad auctores, „Terminus” 13 (2011), z. 24, s. 31-40.

The Meaning of Courtly Love. Papers of the First Annual Conference of the Center for Medieval and Early Renaissance Studies, ed. by F.X. Newman, Albany 1968.

Metryka Uniwersytetu Krakowskiego z lat 1400-1508, wyd. A. Gąsiorowski, T. Jurek, I. Skierska, Kraków 2004.

Michałowska T., Epistola amatoria, w: eadem, Literatura polskiego średniowiecza. Leksykon, Warszawa 2011, s. 233-238.

Michałowska T., Średniowieczna teoria literatury w Polsce. Rekonesans, Wrocław 2007.

Minnis A., Medieval Theory of Authorship. Scholastic Literary Attitudes in the Later Middle Ages, Philadelphia 2010.

Morel-Fatio A., Mélanges de littérature catalane. III - Le livre de courtoisie, „Romania" 15 (1886), s. 192-235.

Olsen B.M., Ovide au Moyen Âge (du IX $X^{e}$ au XII ${ }^{e}$ siècle), w: Le Strade del testo, a cura di G. Cavallo, Bari 1987, s. 67-96.

Ovid in the Middle Ages, ed. by J.G. Clark, F.T. Coulson, K.L. McKinley, Cambridge 2011.

Ovide, L'art d’aimer, texte établi et traduit par H. Bornecque, Paris 1994.

Owidiusz, Sztuka kochania, przeł. E. Skwara, Wrocław 2016.

Ożóg K., Uczeni w monarchii Jadwigi Andegaweńskiej i Władysława Jagiełty (13841434), Kraków 2004.

Paris G., Études sur les romans de la Table Ronde : "Lancelot du Lac », „Romania” 12 (1883), s. 459-534.

Pellegrin E., Les " Remedia amoris » d'Ovide, texte scolaire médiéval, „Bibliothèque de l'école des Chartes" 115 (1957), s. 172-179.

Quain E.A., The Medieval Accessus ad Auctores, „Traditio” 3 (1945), s. 215-264.

de Rougemont D., Miłość a świat kultury zachodniej, przeł. L. Eustachiewicz, Warszawa 1968.

Ruhe E., „De amasio ad amasiam“: Zur Gattungsgeschichte des mittelalterlichen Liebesbriefes, München 1975.

Sanford E.M., The Use of Classical Latin Authors in the Libri Manuales, „Transactions and Proceedings of the American Philological Association" 55 (1924), s. $190-248$.

Segre C., Le forme e tradizioni didattiche, w: Grundriss der romanischen Literaturen des Mittelalters, hrsg. von H.U. Gumbrecht, U. Mölk, Bd. 6, La littérature didactique, allegorique et satirique, hrsg. von H.R. Jauss, Heidelberg 1968, s. 56-145. 
Stopka K., Szkoły katedralne metropolii gnieźnieńskiej w średniowieczu. Studia nad kształceniem kleru polskiego w wiekach średnich, Kraków 1994.

Stopka K., Zakres i program nauczania septem artes w szkołach katedralnych, w: Septem artes $w$ kształtowaniu kultury umysłowej w Polsce średniowiecznej. Wybrane zagadnienia, red. T. Michałowska, Wrocław 2007, s. 125-136.

Szujski J., Założenie i urządzenie Collegii Minoris, „Archiwum do Dziejów Literatury i Oświaty w Polsce", Seria I, 1 (1878), s. 95-97.

Tarrant R., Ovid: "Amores", "Ars amatoria", "Remedia amoris", w: Texts and Transmission. A Survey of the Latin Classics, ed. by L.D. Reynolds, Oxford 1983, s. 257-262.

Thiel E.J., Mittellateinische Nachdichtungen von Ovids „Ars amatoria“ und „Remedia amoris“, „Mittellateinisches Jahrbuch” 5 (1968), s. 115-180.

Thiel E.J., Neue Handschriften der mittellateinischen Nachdichtungen von Ovids „Ars amatoria“ und „Remedia amoris" und Nachträge, „Mittellateinisches Jahrbuch” 9 (1974), s. 248-268.

Ulanowski B., Liber formularum ad ius Polonicum necnon canonicum spectantium in codice Regiomontano asservatarum, Cracoviae 1895.

Watson P., Praecepta Amoris. Ovid's Didactic Elegy, w: Brill's Companion to Ovid, ed. by B.W. Boyd, Leiden 2002, s. 141-166.

Wattenbach W., Pseudoovidische Gedichte des Mittelalters, „Zeitschrift für deutsches Altertum" 34 (1890), s. 270-280.

Włodarski M., Średniowieczna poezja łacińska w Polsce, Wrocław 2007.

Woods M.C., Rape and the Pedagogical Rhetoric of Sexual Violence, w: Criticism and Dissent in the Middle Ages, ed. by R. Copeland, Cambridge 1996, s. 56-86.

Woods M.C., Using the Poetria nova to Teach Dictamen in Italy and Central Europe, w: Papers on Rhetoric. V. Atti del Convegno Internazionale "Dictamen, Poetria and Cicero: Coherence and Diversification" (Bologna, 10-11 maggio 2002), ed. by Calboli Montefusco, Roma 2003, s. 261-279. 